\title{
Performance Analysis of UAE Banks-An Exploratory Study
}

\author{
K. Ravichandran ${ }^{1} \&$ H. I. Ahmad ${ }^{1}$ \\ ${ }^{1}$ School of Management, New York Institute of Technology, Abu Dhabi Campus, UAE \\ Correspondence: K. Ravichandran, School of Management, New York Institute of Technology, Abu Dhabi \\ Campus, UAE. Tel: 97-124-048-760. E-mail: kravicha@ nyit.edu
}

Received: June 4, 2015

doi:10.5539/ijef.v7n9p200
Accepted: July 13, 2015

Online Published: August 25, 2015

URL: http://dx.doi.org/10.5539/ijef.v7n9p200

\begin{abstract}
In this research study, we propose an alternative empirical technique for the performance of UAE top 5 banks (initially) in comparison with global banks. The comparative ratio analysis has been performed and the UAE based banks are ranked as per their performance. The findings of this appraoch are important in the context recent banking and financial crisis, the methodology can be used as a pedagogical benchmarking exercise in or outside the class room at undergraduate and graduate level and can also serve as an important input for performance analysis research studies.
\end{abstract}

Keywords: financial performance, financial ratios, commercial banks, performance evaluation, UAE

\section{Introduction}

Financial ratios are tools to analyze the performance of a company and are mostly drawn from two key financial statements; statement of financial position and income statement, Gitman (2009). The analysis helps identify the weak and strong performance areas of a firm, James (2013). And, this assist management to determine the direction of the company, Payne (2011). The results are useful for decision making purposes Madura (2009). With the help of ratios a comparison can be made of the pre- and post-action results. Hence, they are helpful in identifying success or otherwise of a particular choice of action.

When it comes to financial institution performance analysis, Elizabith and Greg (2004) showed that all financial performance measures such as interest margins, return on assets, and capital adequacy are positively correlated with customer service quality scores. And, Arzu and Gokhan (2005) discussed the asset and liability management in financial crisis. They argued that an efficient asset-liability management requires maximizing bank's profit as well as controlling and lowering various risk, and their study showed how shifts in market perceptions can create trouble during crisis. Bayraktar and Wang (2004), investigated firstly the impact of foreign bank entry on the performance of domestic banks, and secondly how this relationship is affected by the sequence of financial liberalization. The authors indicated that the sequence of financial liberalization matters for the performance of domestic banking sector. After controlling for macroeconomic variables and grouping countries by their sequence of liberalization, foreign bank entry has significantly improved domestic bank competitiveness in countries which liberalized their stock potentially low profits, compared to other banks. A high ATD ratio presents the risk that some loans may have to be sold at a loss to meet depositors' claims. Misir (1998) have used this ratio for measuring liquidity of a bank.

From the merging market standpoint, Mohammad Omar Faruk (2014) made a comparative study on the Bangladeshi banks performance using Profitability Ratio, Liquidity Ratio, Risk Measurement Ratio and DuPont Analysis and reported the results based on the these ratios. A comparative analysis of commercial banking performance in Bangladesh was conducted by Malek (2005). The author studied Nationalized Commercial Bank, Local Private Commercial Banks and Foreign Commercial Banks operating during 1999 to 2002 and noted that the foreign banks outperformed the local banks.

The macroeconomic changes in the UAE has led to a strong growth in the banking sector. According UAE central bank, the assets grew at the rate 36\% since 2008. In the year 2013 the deposits grew at $8.8 \%$, loan and advances to $7.2 \%$ and the non-resident deposits grow at $10 \%$ depicting this growth phenomenon. And, making UAE based banks performance in comparison with global banks an interesting area of study.

From the perspective of Basel III, the capital requirements present an opportunity for Middle East banks and regulators to embrace new rules and improve the sector's asset quality and risk-return profiles. The Basel III 
Guidelines maintains the amount of minimum capital required at $8 \%$ of risk weighted assets. he total amount of Tier 1 capital now required under Basel III Guidelines is $6 \%$ out of which Core Tier 1 is required to be $4.5 \%$ (against the Basel II requirement of 2\%). The Core Tier 1 can consist of ordinary share capital and retained earnings. The Additional 1.5\% Tier 1 capital may consist of ordinary shares/retained earnings (if the bank so chooses), but other instruments are permitted to make up the difference. The criteria for inclusion in Core Tier 1, Additional Tier 1 and Tier II are detailed in the Basel III Guidelines. At present the minimum capital requirement in the UAE is $12 \%$ and Tier 2 capital under the UAE Central Bank rules can only be a maximum of $67 \%$ of Tier 1 capital. Considering that many of the UAE local banks already have high level of capital adequacy, the Basel III changes may not substantially impact the requirements of capital profile of the local banks. The Basel III Guidelines now proposes two liquidity constraints on a bank's portfolio: (a) the Liquidity Coverage Ratio (LCR); and (b) the Net Stable Funding Ratio (NSFR). The former is designed to promote banks' short-term resilience to liquidity shocks, whilst the latter is designed to address liquidity mismatches and aims to give banks an incentive to fund themselves on an on-going basis with more stable sources of funding. Banks in the UAE have sizeable capital buffers by international standards. UAE Banks are holding high levels of high-quality capital. UAE capital adequacy frameworks are broadly in line with the Basel II accord and are moving toward Basel III regulations. The current high capitalization of UAE banks will make it easier for them to move to and comply with Basel III standards. UAE banks' gross exposures are concentrated in claims on corporates, sovereigns, and public sector entities. Net exposures after credit risk mitigation (CRM) represented about 90 percent of gross exposures at end-2013. Total provisions in UAE banks generally fully cover nonperforming loans (Gurauv Jain \& Sakshi Puri, 2014; IMF, 2014).

Predicting the profitability and efficiency of banks, searching for some key banking characteristics is an important area research. For this purpose, Bashir (2001), examined the determinants of Islamic banks' performance across eight Middle Eastern countries between 1993 and 1998. The results indicate that high leverage and large loans to asset ratios lead to higher profitability. The results also indicate that foreign-owned banks are more profitable than their domestic counterparts. Everything remaining equal, there is an evidence that implicit and explicit taxes affect the bank performance measures negatively. Moreover, favorable macroeconomic conditions impact performance measures positively. Even stock markets are complementary to bank financing. Advance to deposit (ATD) ratio is the most commonly used liquidity ratio of a bank. Misir (1998) and Hossain and Bhuiyan (1990), have used this ratio for measuring liquidity of a bank. Federal Reserve Bank of Dallas also uses this ratio. A low ratio of ATD indicates excess liquidity.

This research study is different from all the previous comparative performance analysis studies, here, we first discuss the performance of UAE based banks in comparison with top global banks calculated through profitability, credit, liquidity, CAPEX ratios and benchmarking ratio like Price to Earnings and Price to Book. Finally, we present the final ranking of the UAE based banks. The rest of the paper is organized as follows. In the second section of this paper the data and methodology are discussed. Empirical results are presented in the third section. And, fourth section concludes this paper.

\section{Data and Methodology}

This paper tries to compare the UAE banks with the top five global banks. The top ten global banks were identified based on their total assets (http://www.relbanks.com/worlds-top-banks/assets) and out of that five banks namely Agricultural Bank of China Ltd (ABCL), BNP Paribas SA (BNP FP), Bank of China Ltd (BOC), China Construction Bank Corp. (CCBC), Industrial \& Commercial Bank of China Ltd. (ICBC) were chosen based on the data availability. And, the top five UAE banks namely Abu Dhabi Commercial Bank PJSC (ADCB), Dubai Islamic Bank PJSC (DIB), Emirates NBD PJSC(ENBD), First Gulf Bank PJSC(FGB), National Bank of Abu Dhabi PJSC (NBAD) were also identified and five years financial (2010-2014) and key ratios were collected from Bloomberg and the analysis were conducted based on these. Based on the various ratio averages of top global banks UAE banks were ranked and the best banked is identified through this exercise.

\section{Empirical Analysis}

In this section we present the and discuss the analysis obtain through different performance ratios like profitability, Credit, liquidity, CAPEX ratios and Du Pont analysis. 


\subsection{Profitability}

Table 1. Profitability ratios

\begin{tabular}{lcccccccccc}
\hline & \multicolumn{1}{c}{ Global Banks } & \multicolumn{4}{c}{ UAE Banks } \\
\hline Financial ratio's & ABCL & BNP & BOC & CCBC & ICBCL & ADCB & DIB & ENBD & FGB & NBAD \\
Return on Common Equity & 20.81 & 9.85 & 16.7 & 21.08 & 20.88 & 10.5 & 14.2 & 9.35 & 17.3 & 18.06 \\
Return on Assets & 0.99 & 0.32 & 1.08 & 1.35 & 1.29 & 1.14 & 1.59 & 1.02 & 2.8 & 1.74 \\
Return on Capital & 7.53 & 0.56 & 5.37 & 8.81 & 7.78 & 3.45 & 7.82 & 3.31 & 10.2 & 5.31 \\
Operating Margin & 38.7 & 20.4 & 46.7 & 51.76 & 53.04 & 27.52 & 35.7 & 28.84 & 59.2 & 53.07 \\
Net Income Margin & 30.09 & 14.1 & 34.7 & 39.38 & 41 & 31.15 & 37.8 & 31.4 & 60.1 & 51.55 \\
Net Income to Common Margin & 30.09 & 13.7 & 34.7 & 39.38 & 41 & 31.15 & 37.8 & 31.4 & 60.1 & 51.55 \\
Dvd. Payout Ratio & 26.15 & 32.9 & 40.6 & 43.51 & 41.62 & 0.78 & 0.62 & 0.94 & 0.29 & 2.89 \\
Sustainable growth & 14.24 & 6.56 & 10 & 12.04 & 12.36 & 32.48 & 53.5 & 43.52 & 33.8 & 22.3 \\
\hline
\end{tabular}

From the profitability ratio perspective, it is evident the UAE banks are performing better than that of the global banks in terms of returns, net income and sustainability. But the UAE banks are far behind when it comes to the dividend payout ratio. Keeping the shareholders happy is the important objective of financial management, but in UAE the story is different, most of the banks are partly government owned or the major shareholders are the rulers of the state, so offering less dividend will not affect the company in a big way. Another perspective on this can be the growth opportunities (Expo: 2020 etc.) that are present in the UAE perhaps influence management decision on dividend.

\subsection{Credit}

Table 2. Credit ratios

\begin{tabular}{lcccccccccc}
\hline & \multicolumn{4}{c}{ Global Banks } & \multicolumn{4}{c}{ UAE Banks } \\
\hline Financial ratio's & ABCL & BNP & BOC & CCBC & ICBCL & ADCB & DIB & ENBD & FGB & NBAD \\
Total Debt/EBIT & 7.7 & 161.1 & 10.9 & 5.6 & -6.9 & 16.3 & 8.4 & 22.3 & 4.6 & 13.9 \\
Net Debt/EBIT & -10.9 & 144.3 & -6.6 & -5.9 & 6.6 & 10.5 & 10.8 & 11.2 & 16.2 & 10 \\
Net Debt/Equity & 252.8 & 1350 & 131.2 & 150.5 & 166.5 & 42.7 & 52.9 & 76.4 & 49.7 & 60.5 \\
Net Debt/Capital & -95.3 & 82.6 & -42.8 & -63.2 & 62.8 & 16.7 & 26.9 & 26.4 & 29.2 & 18.3 \\
Tot loan/tot deposits & 2 & 2.9 & 1.8 & 1.9 & 2 & 1.2 & 0.9 & 1.1 & 0.9 & 0.9 \\
\hline
\end{tabular}

UAE banks net debt to capital was surprisingly high. Overall, debt levels in UAE banks are considerably high when compared to the global banks. And the good news to the UAE banks is that their total loan to deposits ratio is at par with the global banks.

\subsection{Liquidity}

Table 3. Liquidity ratios

\begin{tabular}{lcccccccccc}
\hline & \multicolumn{1}{c}{ Global Banks } & \multicolumn{4}{c}{ UAE Banks } \\
\hline Financial ratio's & ABCL & BNP & BOC & CCBC & ICBCL & ADCB & DIB & ENBD & FGB & NBAD \\
Long-Term Debt/Equity & 54.9 & 768.2 & 49.6 & 23.1 & 17.2 & 43 & 53 & 76 & 50 & 60.5 \\
Long-Term Debt/Capital & 19.9 & 48.42 & 15 & 9.66 & 6.13 & 17 & 27 & 26 & 29 & 18.3 \\
Long-Term Debt/Total Assets & 2.86 & 30.06 & 3.32 & 1.48 & 1.08 & 5.5 & 6.1 & 8.3 & 8.2 & 6.02 \\
Total Debt/Equity & 174 & 151.9 & 221 & 142 & 173 & 195 & 86 & 187 & 71 & 236 \\
$\quad$ Growth (YoY) & 18.3 & -5.77 & 14.8 & 11.3 & -3.7 & -6 & 5.6 & -14 & 15 & 2.31 \\
Total Debt/Capital & 62.8 & 93.31 & 68.1 & 58.4 & 62.9 & 65 & 44 & 62 & 41 & 69.5 \\
Total Debt/Total Assets & 8.93 & 59.04 & 14.9 & 9.16 & 10.9 & 23 & 9.9 & 20 & 12 & 23 \\
CFO/Total Liabilities & -1.96 & 1.45 & -0.74 & -0.59 & -1.2 & 2.2 & 0.2 & 1.4 & 3.4 & 2.17 \\
CFO/Capex & -8.97 & 17.18 & -2.94 & -2.53 & -9 & 24 & -2 & 4.8 & 33 & 6.52 \\
Common Equity/Total Assets & 2.36 & 3.32 & 6.43 & 6.44 & 6.22 & 11 & 11 & 11 & 16 & 9.99 \\
\hline
\end{tabular}


Form the liquidity point of view the debt level is the issue with the UAE banks and the growth rate of the UAE banks is also at par with that of the global banks.

\subsection{Dupont}

Table 4. Dupont ratios

\begin{tabular}{lcccccccccc}
\hline & \multicolumn{4}{c}{ Global Banks } & \multicolumn{4}{c}{ UAE Banks } \\
\hline Financial ratio's & ABCL & BNP & BOC & CCBC & ICBCL & ADCB & DIB & ENBD & FGB & NBAD \\
EBIT/Revenue \% & 38.7 & 20.4 & 46.7 & 51.8 & 53 & 27.5 & 35.7 & 28.8 & 59.2 & 53.1 \\
Revenue/Avg Assets & 0.1 & 0 & 0.1 & 0.1 & 0.1 & 0.1 & 0.1 & 0.1 & 0.1 & 0 \\
Avg Assets/Avg Equity & 20.1 & 32.4 & 15.5 & 15.7 & 16.2 & 9.6 & 9.3 & 9 & 6.1 & 10.3 \\
Adjusted Return on Equity & 20.7 & 10.1 & 16.7 & 21.1 & 20.7 & 10.5 & 14.3 & 9.4 & 17.3 & 18.1 \\
5 Year Average Adj ROE & 20.7 & 12.5 & 15.6 & 20.3 & 20.4 & 12.6 & 18 & 8.9 & 18.5 & 22.2 \\
Payout Ratio & 26.2 & 32.9 & 40.6 & 43.5 & 41.6 & 32.5 & 53.5 & 43.5 & 33.8 & 22.3 \\
Sustainable Growth Rate & 14.2 & 6.6 & 10 & 12 & 12.4 & 7.5 & 6.8 & 5.7 & 11.8 & 14.2 \\
\hline
\end{tabular}

The Du Pont analysis is a method of financial performance measurement that was started by the DuPont Corporation (Investopedia) in the 1920s. With this method assets are measured at their gross book value rather than at net book value in order to produce a higher return on equity (ROE). It is also known as "DuPont identity". From the above analysis, it is inferred that the ROE of ADCB and ENBD banks were less than the industry average. Also we can find that all the banks were performing well and their growth also seems to be good except ENBD, where the performance is not high when considered the industry.

\subsection{Capex}

Table 5. Capex ratios

\begin{tabular}{|c|c|c|c|c|c|c|c|c|c|c|}
\hline \multirow[b]{2}{*}{ Financial ratio's } & \multicolumn{5}{|c|}{ Global Banks } & \multicolumn{5}{|c|}{ UAE Banks } \\
\hline & $\mathrm{ABCL}$ & BNP & $\mathrm{BOC}$ & $\mathrm{CCBC}$ & ICBCL & $\mathrm{ADCB}$ & DIB & ENBD & FGB & NBAD \\
\hline Tier 1 Risk-Based Capital Ratio & 8.6 & 10.7 & 10.1 & 10.5 & 10.4 & 14.8 & 13.7 & 12.5 & 17.3 & 15.2 \\
\hline Total Risk-Based Capital Ratio & 10.8 & 13.4 & 12.8 & 12.9 & 13 & 18 & 16.4 & 17.9 & 19.3 & 18.8 \\
\hline Tot loan/tot deposits & 58.2 & 126.2 & 70.3 & 63.2 & 61.3 & 126.5 & 87.9 & 115.2 & 100.2 & 103 \\
\hline Non-Perf Assets/Total Assets & 3.2 & 1.8 & 0.9 & 0.8 & 0.9 & 3.4 & 4.7 & 6.1 & 1.6 & 1.3 \\
\hline Non-Perf Assets/Total Loans & 5.5 & 5.4 & 1.7 & 1.6 & 1.8 & 4.7 & 7.3 & 8.1 & 2.3 & 2.2 \\
\hline Loan Loss Reserves/Non-Perf Assets & 178.8 & 70 & 176.6 & 190.5 & 178.2 & 101.2 & 207 & 76.8 & 135.7 & 117.2 \\
\hline Loan Loss Reserves/Total Loans & 6.3 & 3.6 & 2.5 & 2.7 & 2.6 & 3.7 & 11.9 & 4.4 & 2.6 & 2.4 \\
\hline Cap \& Loan Loss Res/Non-Perf Assets & 630.1 & 328.3 & 1113.9 & 1079.4 & 1061.4 & 664.5 & 514.1 & 582.4 & 1606.7 & 1011.4 \\
\hline Prov for Loan Losses/Total Loans & 1.1 & 0.7 & 0.3 & 0.6 & 0.5 & 1.7 & 1.3 & 1.7 & 1.4 & 0.8 \\
\hline Actual Loan Loss/Prov for Loan Loss & 6.1 & 90.5 & 34.8 & 21.7 & 28.8 & 41.8 & 12.4 & 6.9 & 48.2 & 31.5 \\
\hline Loan Loss Coverage & 2341 & 4.5 & 47.5 & 43 & 36.5 & 24.4 & 359.5 & 121.2 & 38.2 & 35.7 \\
\hline
\end{tabular}

CAPEX ratios are basically measure the funds used by a company to acquire or upgrade physical assets such as property, industrial buildings or equipment. This type of outlay is made by companies to maintain or increase the scope of their operations, when this is applied to banks the asset performance is mainly considered. It is found that the risk based assets are considerably very high in the UAE banks and also in the risk in theTier1 ratio with UAE banks is high when compared to the global industry average.

\subsection{Bench Mark Ratios}

Table 6. Bench mark ratios

\begin{tabular}{lcccccccccc}
\hline & \multicolumn{4}{c}{ Global Banks } & \multicolumn{4}{c}{ UAE Banks } \\
\hline Financial ratio's & ABCL & BNP & BOC & CCBC & ICBCL & ADCB & DIB & ENBD & FGB & NBAD \\
Price/EPS & 43.8 & 21.1 & 49.9 & 52.6 & 54.8 & 33.7 & 33.5 & 25.7 & 58.2 & 50 \\
Price/Book & 6.5 & 9.3 & 5.9 & 8.1 & 8.5 & 11.8 & 10.7 & 8.3 & 10 & 10.5 \\
\hline
\end{tabular}


Except ENBD all the UAE banks were performing in line with the industry standard.

Table 7. Best Banks by order of their performance compared to top global banks derived from the period (2010-2014)

\begin{tabular}{|c|c|c|c|c|c|}
\hline \multirow[t]{2}{*}{ Key Parameters } & \multicolumn{5}{|c|}{ Ranking of UAE Banks } \\
\hline & $\mathrm{ADCB}$ & DIB & ENBD & FGB & NBAD \\
\hline Average & 3.29 & 3.76 & 4.38 & 1.61 & 1.93 \\
\hline Ranking & 3 & 4 & 5 & 1 & 2 \\
\hline & ADCB & DIB & ENBD & FGB & NBAD \\
\hline
\end{tabular}

The ranking on various financial ratios (see Appendix) of UAE banks infers that the top performing bank is UAE is First Gulf Bank followed by NBAD and the lease performing bank was ENBD.

\section{Discussion and Conclusion}

Efficient performing bank is identified through their Asset Performance (Arzu \& Gokhan, 2005), from the analysis it is evident the best performing bank in UAE is First Gulf Bank. All the UAE are performing almost to the industry standards but the asset performance and total loans should be checked and kept under control. With the BASEL II norms fully implemented in UAE, it is important to check the asset performance by lowering the risk level in the Tier1 assets. Also the growth of the UAE banks YoY was considerably underperforming, so the UAE banks has to take steps to improve their performance in order to keep their race against the global banks. The current high capitalization of UAE banks will make their transition towards Basel III compliance easier.

\section{References}

Arzu, T., \& Gokhan, G. (2005). Asset and Liability management in financial crises. The Journal of Risk Finance, $6(2), 35-49$.

Bashir, A. H. M. (2001). Assessing the Performance of Islamic Banks: Some Evidence from the Middle East. Annual meeting of the MEEA/American economic Association annual Meeting, New Orleans, Louisiana.

Bayraktar, N., \& Wang, Y. (2004, February 20). Foreign Bank Entry, Performance of Domestic Banks and the Sequence of Financial Liberalization. WBIPR .

Elizabeth, D., \& Greg, E. (2004). Efficiency, customer service and financial performance among Australian financial Institutions. International Journal of bank marketing, 22(5), 319-342. http://dx.doi.org/10.1108/02652320410549647

Gitman, L. J. (2009). Principles of Managerial Finance (12th ed.). New York: Prentice Hall.

Hossain, M. K., \& Bhuiyan, R. H. (1990). Performance Dynamics of Nationalized Commercial Banks in Bangladesh-The case of Sonali bank. The Dhaka University Studies, 11(1), 163-174.

IMF. (2014, October 1). Retrieved July 7, 2015, from https://www.imf.org/external/np/pp/eng/2014/102514.pdf

Jain, G., \& Puri, S. (2014, September). Retrieved July 7, 2015, from http://www.tamimi.com/en/magazine/law-update/section-8/september-4/proposed-changes-in-the-capital-an d-liquidity-requirements-for-banks-in-uae.html

James, K. (2013). What Are the Types of Financial Ratios Used to Analyze Financial Performance? African Journal of Business Management, 5(35), 235- 269.

Khan, H. A. R., Ahmed, M., \& Latif, E. (1993). Foreign Banks in Bangladesh: Performance \& Limitations. Dhaka University Journal of Business Studies, 14(1), 185-198.

Luckham, W. R. (1982). Financial Ratio Analysis for Decision-Making. Journal of Arboriculture, 8(11), 296-301.

Madhura, J. (2009). Financial markets and Institutions (7th ed.). USA: Thomson South Western.

Malek, M. (May-June, 2005). A Comparative Analysis of Commercial Banking Performance in Bangladesh. The Cost and Management, 29-33.

Misir, M. A. (1998). Approaches to the Liquidity Management of Commercial Banks: A Critical Review. Dhaka University Journal of Business Studies , 19(2), 275-291.

Mohammad, O. F., \& Rokshana, A. (2014). A Comparative Financial Performance Analysis of Bangladeshi 
Private Commercial Banks. International Journal of Information, Business \& Management, 6(1), 129-146. Payne, R. (2011). Finance's Role in the Organization. Institute of Chartered Accountants in England and Wales.

\section{Appendix}

\begin{tabular}{|c|c|c|c|c|c|}
\hline \multirow[t]{2}{*}{ Key Parameters } & \multicolumn{5}{|c|}{ RANKING of Banks } \\
\hline & $\mathrm{ADCB}$ & DIB & ENBD & FGB & NBAD \\
\hline Market Capitalization & 4 & 5 & 3 & 2 & 1 \\
\hline Book Value of Equity & 3 & 4 & 5 & 1 & 2 \\
\hline Total Deposits & 3 & 4 & 5 & 1 & 2 \\
\hline Total Loans & 3 & 4 & 5 & 1 & 2 \\
\hline Total Assets & 3 & 4 & 5 & 1 & 2 \\
\hline Net Revenue & 4 & 3 & 5 & 1 & 2 \\
\hline Growth \%, YoY & 4 & 3 & 5 & 2 & 1 \\
\hline Profit bef. Provisions & 3 & 4 & 5 & 1 & 2 \\
\hline Margin \% & 3 & 5 & 4 & 1 & 2 \\
\hline Operating Income & 4 & 3 & 5 & 1 & 2 \\
\hline Margin $\%$ & 3 & 4 & 5 & 1 & 2 \\
\hline Net Income Before XO & 3 & 4 & 5 & 1 & 2 \\
\hline Margin $\%$ & 3 & 4 & 5 & 1 & 2 \\
\hline Adjusted EPS & 4 & 5 & 3 & 1 & 2 \\
\hline Growth \%, YoY & 3 & 4 & 5 & 1 & 2 \\
\hline Tier 1 Capital Ratio \% & 3 & 4 & 5 & 1 & 2 \\
\hline Total Capital Ratio \% & 3 & 4 & 5 & 1 & 2 \\
\hline + Cash From Operations & 4 & 5 & 2 & 1 & 3 \\
\hline + Capital Expenditures & 3 & 4 & 5 & 1 & 2 \\
\hline Free Cash Flow & 3 & 4 & 5 & 1 & 2 \\
\hline Market Capitalization & 4 & 5 & 3 & 2 & 1 \\
\hline Free Cash Flow Yield & 3 & 4 & 5 & 1 & 2 \\
\hline Return on Common Equity & 4 & 3 & 5 & 1 & 2 \\
\hline Return on Assets & 4 & 3 & 5 & 1 & 2 \\
\hline Return on Capital & 4 & 3 & 5 & 1 & 2 \\
\hline Operating Margin & 3 & 4 & 5 & 1 & 2 \\
\hline Net Income Margin & 5 & 3 & 4 & 1 & 2 \\
\hline Net Income to Common Margin & 5 & 3 & 4 & 1 & 2 \\
\hline Dvd Payout Ratio & 3 & 4 & 2 & 5 & 1 \\
\hline Sustainable growth & 4 & 1 & 2 & 3 & 5 \\
\hline Return on Common Equity & 3 & 4 & 5 & 2 & 1 \\
\hline Return on Capital & 3 & 4 & 5 & 2 & 1 \\
\hline Operating Margin & 4 & 2 & 5 & 1 & 3 \\
\hline Price/EPS & 4 & 3 & 5 & 1 & 2 \\
\hline Price/Book & 3 & 4 & 5 & 2 & 1 \\
\hline Total debt & 3 & 4 & 5 & 2 & 1 \\
\hline Short-Term Debt & 3 & 4 & 5 & 1 & 2 \\
\hline Long Term Debt & 3 & 4 & 5 & 2 & 1 \\
\hline Total Debt/EBIT & 3 & 4 & 5 & 2 & 1 \\
\hline Net Debt/EBIT & 3 & 4 & 5 & 2 & 1 \\
\hline Common Equity/Total Assets & 3 & 4 & 5 & 2 & 1 \\
\hline Net Debt/Equity & 5 & 1 & 3 & 2 & 4 \\
\hline Net Debt/Capital & 5 & 1 & 4 & 2 & 3 \\
\hline Long-Term Debt/Equity & 5 & 1 & 4 & 2 & 3 \\
\hline Long-Term Debt/Capital & 3 & 4 & 5 & 1 & 2 \\
\hline Long-Term Debt/Total Assets & 1 & 3 & 5 & 2 & 4 \\
\hline Total Debt/Equity & 1 & 4 & 3 & 5 & 2 \\
\hline Growth (YoY) & 3 & 4 & 5 & 1 & 2 \\
\hline Total Debt/Capital & 4 & 2 & 3 & 1 & 5 \\
\hline
\end{tabular}




\begin{tabular}{|c|c|c|c|c|c|}
\hline Total Debt/Total Assets & 1 & 4 & 2 & 5 & 3 \\
\hline CFO/Total Liabilities & 2 & 5 & 3 & 4 & 1 \\
\hline CFO/CapEx & 4 & 5 & 2 & 3 & 1 \\
\hline Common Equity/Total Assets & 3 & 4 & 5 & 1 & 2 \\
\hline Net Inc to Comn/Pre-Tax Profit \% & 3 & 4 & 5 & 1 & 2 \\
\hline Normlzd Net Inc/Net Inc to Cmn & 3 & 4 & 5 & 1 & 2 \\
\hline EBIT/Revenue \% & 4 & 5 & 1 & 2 & 3 \\
\hline Revenue/Avg Assets & 3 & 4 & 5 & 1 & 2 \\
\hline Avg Assets/Avg Equity & 4 & 3 & 5 & 1 & 1 \\
\hline Adjusted Return on Equity & 2 & 3 & 4 & 1 & 5 \\
\hline 5 Year Average Adj ROE & 3 & 4 & 5 & 2 & 1 \\
\hline Payout Ratio & 3 & 5 & 4 & 2 & 1 \\
\hline Sustainable Growth Rate & 3 & 5 & 4 & 2 & 1 \\
\hline Tier 1 Risk-Based Capital Ratio & 3 & 5 & 4 & 2 & 1 \\
\hline Total Risk-Based Capital Ratio & 3 & 4 & 5 & 1 & 2 \\
\hline Tier 1 Capital & 3 & 4 & 5 & 2 & 1 \\
\hline Risk based cap & 3 & 4 & 5 & 2 & 1 \\
\hline Risk-Weighted Assets & 3 & 4 & 5 & 1 & 2 \\
\hline Tot loan/tot dep & 5 & 1 & 3 & 2 & 4 \\
\hline Non-Perf Assets/Total Assets & 3 & 4 & 5 & 2 & 1 \\
\hline Non-Perf Assets/Total Loans & 3 & 5 & 4 & 2 & 1 \\
\hline Loan Loss Reserves/Non-Perf Assets & 3 & 4 & 5 & 1 & 2 \\
\hline Loan Loss Reserves/Total Loans & 3 & 5 & 4 & 2 & 1 \\
\hline Cap \& Loan Loss Res/Non-Perf Assets & 3 & 4 & 5 & 1 & 2 \\
\hline Prov for Loan Losses/Total Loans & 4 & 3 & 5 & 2 & 1 \\
\hline Actual Loan Loss/Prov for Loan Loss & 3 & 5 & 4 & 2 & 1 \\
\hline Loan Loss Coverage & 3 & 4 & 5 & 1 & 2 \\
\hline Average & 3.289474 & 3.763158 & 4.381579 & 1.618421 & 1.934211 \\
\hline \multirow[t]{2}{*}{ Ranking } & 3 & 4 & 5 & 1 & 2 \\
\hline & ADCB & DIB & ENBD & FGB & NBAD \\
\hline
\end{tabular}

\section{Copyrights}

Copyright for this article is retained by the author(s), with first publication rights granted to the journal.

This is an open-access article distributed under the terms and conditions of the Creative Commons Attribution license (http://creativecommons.org/licenses/by/3.0/). 